Willen zur Zusammenarbeit das gleiche Ziel verfolgen. Dies wird eine der vordringlichsten Aufgaben der angewandten Geographie für die kommenden Jahre sein.

Zum Schluß bleibt uns die angenehme Pflicht, allen am Zustandekommen dieses Heftes Beteiligten herz- lich zu danken. In erster Linie sind dies die Autoren, die sich spontan bereit erklärt haben, ihre wertvolle Erfahrung hier einfließen zu lassen. Danken möchten wir aber auch der Redaktion der Geographica Helvetica, welche uns bereitwillig die vorliegende Publikation ermöglicht hat.

\title{
La géographie appliquée en Suisse - réflexions sur sa position dans le champ des activités de notre société
}

\author{
Traduction: Cornelia Mayerhofer, Zurich
}

Il n'y a pas longtemps que les géographes actifs en geographie appliquée étaient presque regardés comme les exemplaires exotiques d'un groupe professionnel qui n'aurait d'autres places que dans l'enseignement. Le développement et la transformation toujours plus intensifs de notre paysage - et surtout leurs conséquences qui s'avèrent de plus en plus négatives pour notre environnement et les bases naturelles de la vie ont entre-temps convaincu le public que la géographie appliquée a le pouvoir de contribuer à la protection des bases naturelles de la vie et à la création d'un environnement optimal pour l'homme par l'aménagement continu et par la recherche, le planning et l'organisation. La géographie appliquée - et par là nous entendons toutes les activités géographiques en dehors de l'enseignement et la formation permanente - joue donc un rôle toujours plus important dans notre société, avant tout dans les domaines actuels de l'aménagement du territoire et de la protection de l'environnement. La politique et les medias nous montrent presque tous les jours l'actualité des problèmes dans le domaine de la géographie appliquée de notre pays.

A cet égard, il n'est pas surprenant que le nombre des étudiants en géographie inscrits aux universités et écoles polytechniques suisses s'est plus que quadruplé entre 1968 et 1979. Un sondage de la Société suisse de géographie appliquée, qui en 1982 questionna tous les instituts géographiques de notre pays, a clairement révélé que le nombre de nouveaux diplômés en géographie qui visent à gagner leur vie en dehors de l'enseignement dépassera bientôt largement le nombre des emplois offerts. Selon ces données l'on peut estimer que le nombre des étudiants diplômés en 1982/83 égale déjà un tiers de tous les emplois occupés par des géographes. S'y ajoute le fait que la rotation naturelle des emplois ne joue pas encore un rôle à cause de la moyenne d'âge relativement basse des employés.

La Suisse n'est cependant pas le seul pays où la situation s'aggrave. En Allemagne fédérale, par exemple, l'on estime que le nombre de nouveaux diplômés qui visent à gagner leur vie en dehors de l'enseignement augmente de $20 \%$ par an. En 1982/83, cette discipline comptait environ 7000 étudiants, une demande en emplois à laquelle ne s'opposent, dans le cas le plus favorable, que quelques centaines de places.

Vu cette situation - l'actualité des problèmes dans le domaine de la géographie appliquée d'une part et l'impossibilité croissante de trouver un emploi adéquat d'autre part, l'on peut bien se demander si la géographie va de plus en plus avoir lieu sans des géographes. Si l'on constate que les offices fédéraux, qui s'occupent dans une large mesure des domaines de la géographie appliquée, n'emploient aucun géographe et que, dans les organes de recherches, des tâches centrales de notre discipline ne sont pas traitées par des géographes, l'on est incliné à affirmer cette question.

Il ne faut par contre pas oublier que des géographes sont actifs dans de nombreux domaines de notre discipline et aident ainsi à répandre l'image professionnelle des géographes par leur travail. Selon un sondage fait parmi les membres de la Société suisse de géographie appliquée en 1981, les géographes questionnés occupent les positions suivantes:

\begin{tabular}{|lrr|}
\hline Administration & & $46 \%$ \\
- au niveau fédéral & $20 \%$ & \\
- au niveau cantonal & $20 \%$ & \\
- au niveau régional & $4 \%$ & \\
- au niveau municipal & $2 \%$ & \\
Ecoles polytechniques/universités & & $24 \%$ \\
Industrie privée & & $22 \%$ \\
- bureaux d'aménagement et de & & \\
$\quad$ consultation & $11 \%$ & \\
- autres entreprises du secteur tertiaire & $4 \%$ & \\
- géographes indépendants & $7 \%$ & \\
Autres & & $8 \%$ \\
\hline
\end{tabular}

par Ulrich Roth, président de la Société Suisse de Géographie appliquée 
La répartition par domaines d'activité est la suivante:

\begin{tabular}{|lr|}
\hline Aménagement du territoire (secteurs partiels & \\
y compris) & $39 \%$ \\
Economie régionale & $7 \%$ \\
Protection de la nature et du paysage & $17 \%$ \\
Autres domaines de protection de & \\
l'environnement & $1 \%$ \\
Recherches fondamentales et appliquées & $16 \%$ \\
Documentation & $3 \%$ \\
Cartographie, maisons d'édition & $4 \%$ \\
Musées & $3 \%$ \\
Journalisme & $1 \%$ \\
Autres & $9 \%$ \\
\hline
\end{tabular}

Il en ressort de ces deux tableaux que les géographes ont déjà accédé à de nombreux domaines d'activité et y sont acceptés comme de véritables partenaires. Ainsi, les Offices fédéraux de l'agriculture et de l'aménagement du territoire ont chargé la Société suisse de géographie appliquée de l'étude préparatoire d'un programme de recherche national concernant l'utilisation du sol, qui a entre-temps été approuvé par le Conseil fédéral.

La présente revue sur des thèmes de la géographie appliquée vient de paraître à l'occasion d'un symposium qui précédera le Congrès international de géographie à Paris. Ce symposium, qui est organisé par la Société suisse de la géographie appliquée en coopération de l'Ecole polytechnique fédérale de Zurich et de l'Université de Lausanne, aura lieu à Zurich et à Lausanne du 20 au 25 août 1984. L'objectif de cette rencontre sera de préciser les possibilités et les conditions de base pour l'activité des géographes sous leurs divers aspects afin de déterminer leur intégration dans le champ des activités d'aujourd-hui.

Dans le but de communiquer leurs intentions, les organisateurs veulent ouvrir la discussion sur les revendications suivantes:

- Relations plus étroites entre les écoles polytechniques/universités et la pratique. Ces relations permettront de reconnaître les besoins réels plus rapidement et d'en tenir compte à temps dans l'enseignement. Une solution consisterait donc d'intégrer aux études plus de stages en dehors de l'université et d'inviter plus de praticiens pour donner des cours universitaires.

- Meilleure information auprès les étudiants sur les possibilités d'emploi et leurs exigences particulières. Ceci peut être fait par l'actualisation permanente des programmes d'études et des bibliothèques d'institut par la pratique. Ces mesures aident les étudiants à contacter plus facilement les personnes compétentes.

- Spécialisation dans un domaine particulier de la géographie sans négliger les rapports avec d'autres domaines de la discipline. Il est vrai que des possibilités dans le cadre de l'organisation de projets peuvent se présenter aux généralistes; l'entrée dans la vie professionnelle se fait cependant presque toujours au niveau du traitement d'un domaine particulier; y sont surtout demandés des spécialistes capables de ne pas céder à la grande concurrence des disciplines voisines.

- Etendre la réputation de notre profession et intensifier la coopération entre tous les géographes. L'on peut bien se demander - et ceci ressort du sondage de la Société suisse de géographie appliquée pourquoi moins de la moitié des diplômés en géographie appliquée ne se nomment pas géographes. Il est nécessaire que nous présentions nos travaux et nos activités à un vaste public pour attirer son attention sur les possibilités des géographes pour résoudre les problèmes actuels.

Par cette revue, les auteurs cherchent à soulever une discussion entre les géographes eux-mêmes d'une part et de l'autre part aussi dans le public. Il nous semble essentiel d'échanger nos opinions afin d'éviter que nos revendications restent des formules prononcées au bout des lèvres. Nous nous estimons heureux d'avoir pu confier cette tâche à des auteurs de notre profession et à des personnes qui lui sont proches. Il va sans dire que nous ne pouvons pas éclaircir tous les divers aspects de la géographie appliquée en Suisse dans cette publication. Pour souci de clarté nous avons divisé les 15 articles en six groupes:

1. La géographie appliquée - Sa position dans l'aménagement du territoire

2. La géographie appliquée - Relations plus étroites entre la recherche et la pratique

3. La géographie appliquée - Bases des problèmes actuels

4. La géographie appliquée dans le cadre de l'évaluation de gros projets

5. La géographie appliquée - Contribution à la protection de la nature et du paysage

6. La géographie appliquée dans la discussion publique

Nous regrettons de n'avoir pas réussi d'inspirer nos collègues de la Suisse romande et italienne à une contribution, alors que malgré tout la géographie appliquée joue un rôle assez important pour résoudre des problèmes actuels dans ces régions.

Par cette publication, nous espérons mettre en évidence les divers domaines d'activité de la géographie appliquée en Suisse. Nous tenons surtout à montrer qu'il existent encore des possibilités qui peuvent être ouvertes aux géographes, si tous les cercles intéressés poursuivent le même but avec la fermeté nécessaire et la volonté altruiste de coopération. Ceci sera une des tâches les plus urgentes de la géographie appliquée des années à venir. 
Pour terminer, il me reste encore le devoir agréable d'exprimer ma sincère gratitude à tous ceux qui ont contribué à la réalisation de cette revue. Ce sont tout d'abord les auteurs qui ont été spontanément prêts à communiquer leur expérience fortement estimée dans cette publication. Nous aimerions également remercier la rédaction de la Geographica Helvetica, qui a rendu possible cette publication.

\section{Applied Geography in Switzerland - Actual Problems and Future Challenges}

Translation: Cornelia Mayerhofer, Zurich

\begin{abstract}
A few years ago, applied geography was looked upon as a strange profession that should rather devote itself to its assigned task in the educational system. The rapid development and the steadily increasing transformation of our landscape - and above all their consequences, i.e. the increasing destruction of our environment and the natural fundamentals of life have meanwhile convinced the public that applied geography can contribute to the protection and development of an optimal human environment. This can be done by continual area planning, research, project planning and management. Applied geography - and by this we understand all geographical activities except those in education - therefore plays an increasingly important part in our society, above all in the topical fields of area planning and environmental protection. Politics and the media give us an example of the great importance attributed to the problems relating to applied geography in our country.
\end{abstract}

It is therefore not surprising that the number of geography students enrolled at Swiss universities and institutes of technology has more than quadrupled between 1968 and 1979. A survey carried out by the Swiss Society of Applied Geography (which in 1982 investigated all the geographical institutes of Switzerland) clearly shows that the number of newly graduated geographers who do not want to teach will soon exceed the number of job vacancies by far. According to the results of this survey, we may estimate that the number of students who graduated in 1982/83 already equals one third of all positions held by applied geographers. Nevertheless we should bear in mind that the natural rotation of positions has hardly occurred yet, because of the relatively low average age of employed geographers.

However, Switzerland is not the only country where the situation is getting worse. In the Federal Republic of Germany, for instance, the number of newly graduated geographers is estimated to increase by $20 \%$ each year. In 1982/83 some 7000 students were enrolled in geography, with a demand for employment being far greater than the number of vacancies which can be estimated at a few hundred positions at best.

In this situation where problems relating to applied geography are given topical interest on the one hand and where, on the other hand, it becomes increasingly less probable to find a suitable employment after having graduated in geography, we may well ask us whether geography will more and more continue to function without geographers. Considering the facts that the Swiss Federal Offices which are mainly active in the fields of applied geography do not employ a single geographer and that the central tasks of geography are not fulfilled by geographers in research institutes, we may be inclined to answer this question positively.

Nevertheless we should also bear in mind that applied geographers take an active part in many fields of geographical science and thus help to broaden the image of our profession. According to a survey of the Swiss Society of Applied Geography, its members were employed in the following positions in 1981:

\begin{tabular}{|lrc|}
\hline Public administration & & $46 \%$ \\
- at the federal level & $20 \%$ & \\
- at the cantonal level & $20 \%$ & \\
- at the regional level & $4 \%$ & \\
- at the municipal level & $2 \%$ & \\
Universities/Federal & & \\
Institutes of Technology & & $24 \%$ \\
Private sector & & $22 \%$ \\
- planning and consulting offices & $11 \%$ & \\
- other service trades & $4 \%$ & \\
- free-lance activity & $7 \%$ & \\
Other activities & & $8 \%$ \\
\hline
\end{tabular}

by Ulrich Roth, President of the Swiss Society of Applied Geography 